\title{
Results from a survey of the South African GISc community show who they are and what they do
}

\author{
Serena Coetzee ${ }^{1}$, Sanet Eksteen ${ }^{1}$ and Adrian Roos $^{2}$ \\ ${ }^{1}$ Centre for Geoinformation Science, Department Geography, Geoinformatics and Meteorology, \\ University of Pretoria, South Africa, serena.coetzee@up.ac.za \\ ${ }^{2}$ Geo-information Society of South Africa (GISSA), South Africa
}

DOI: http://dx.doi.org/10.4314/sajg.v3i2.8

\begin{abstract}
In the wake of the rapidly increasing global geospatial industry, a shortage of registered GISc professionals, as well as professional GISc registration challenges, have been reported in South Africa. The suitability of registration categories and academic requirements for the type of work performed by GISc professionals has also been questioned. This article presents results of a survey by the Geo-information Society of South Africa (GISSA) to gain a better understanding of who the members of the South African GISc community are and what they do at work. Such understanding is important for the implementation of the new Geomatics Profession Act 19 of 2013, the development of the South African Geo-spatial Information Management Strategy and the establishment of the South African Spatial Data Infrastructure (SASDI). An online questionnaire was distributed and responses analysed. Amongst others, results show that roughly a quarter of all respondents switched to GISc related work later in their career. While individuals tend to focus their work on a few of industries, application areas or disciplines, the GISc community as a whole is active in a wide range of industries, application areas and disciplines. Qualifications that do not meet academic requirements for registration are a significant barrier to registration. Most members of the GISc community fulfil roles of data analysis and interpretation, together with data acquisition, data management, and/or visualization/mapping. The research raises questions whether the differentiation between the type of work performed by different registration categories is clear enough; whether an additional registration category is required for professionals from other disciplines who use GIS as a tool; and why many people who focus on remote sensing are not registered as GISc professionals with PLATO. Survey results contribute to the understanding of the supply and demand for GISc knowledge and skills in South Africa. Additional research is required to better understand the demand and to identify prominent gaps in GISc skills and knowledge.
\end{abstract}

\section{Introduction}

International reports suggest that the geospatial industry is growing rapidly and that demand for GISc knowledge and skills is likely to increase (Cipriano et al. 2013, DOLETA 2011, Dowman and 
Roy 2011, Henttu et al. 2012, Oxera 2013). Anecdotal evidence from meetings, workshops, panel discussions and conferences held in South Africa over the past few years suggests that there is a shortage of registered GISc professionals in South Africa and that many members of the GISc community would like to register but their qualifications do not meet the requirements for professional registration (du Plessis 2012, van Zwieten 2012). Questions have also been raised about the suitability of the PLATO registration categories and the applicability of the PLATO academic model for the type of work performed by GISc professionals on a daily basis (GISSA 2013).

The South African geomatics profession executes its duties and responsibilities in terms of the Professional \& Technical Surveyors' Act 40 of 1984, which established the South African Council for Professional and Technical Surveyors (PLATO) as a professional body for the geomatics profession (South Africa, 1984). The responsibilities of the geomatics professional body include the registration of persons who practice GISc, as well as the accreditation of university GISc degree programmes. In December 2013, the Geomatics Profession Act 19 of 2013 replaced this Act and the South African Geomatics Council is established accordingly (South Africa, 2013). In terms of the new legislation, effective from 2014, all persons practicing in any of the geomatics branches (including GISc) are required to be registered with an appropriate professional body.

Concerns about the supply of tertiary GISc education in Africa, the Southern African Development Community (SADC), and South Africa have been raised (Coetzee and Eksteen 2012, Eksteen et al. 2012, Eksteen and Coetzee 2013, Hill and Nell 1996, Marais 2008). Du Plessis and Van Niekerk (2014) identified three registration challenges: 1) inconsistencies in the knowledge and skills development of GISc professionals; 2) lack of a standard set of competency requirements to assess individuals; and 3) challenges facing universities who prepare students to register as professionals with the PLATO council. Amongst others, this article identifies challenges facing individuals who want to register.

Recent studies suggest the need for revisions to the South African GISc academic model (Du Plessis and Van Niekerk 2013, 2014; Rautenbach et al. 2012). The survey results described in this article shed light on the type of work performed by the members of the South African GISc community and can inform the revision of the GISc academic model. Understanding who the members of the GISc community are and the type of work performed is a prerequisite for understanding and estimating the supply (who is available to do the work) and demand (what kind of work is required) for GISc knowledge and skills. Such understanding is relevant for the implementation of the new Geomatics Profession Act 19 of 2013 and the development of the South African Geo-spatial Information Management Strategy, launched in December 2013 by the Committee for Spatial Information (CSI) responsible for the South African Spatial Data Infrastructure (SASDI).

The Geo-information Society of South Africa (GISSA) is a national, unified, representative (umbrella) body for the geoinformation community of South Africa. It aims to promote and protect 
the interests of its members on all fora (GISSA 2014). In response to these questions and concerns, GISSA initiated a survey among its members. The aim was to gain a quantitative understanding of 1) who the members of the South African GISc community are; 2) what they do on a day-to-day basis at work; and 3) of the adoption rate of statutory professional registration and barriers to registration. The results of the survey will allow GISSA to fulfil its constitutional obligation of protecting the interests of its members on various fora.

First results from the survey were presented at the GISSA Annual General Meeting in Pretoria in March 2014 (Roos 2014). In this article an analyses of the survey results is presented and discussed. The remainder of the article is structured as follows: related work is briefly described in section 2; the methodology for the survey is described in section 3; results and discussion of the results are included in section 4. The subsections of section 4 answer the research questions: 1) 4.1 and 4.3 provide a quantitative understanding of who the members of the GISc community are, their qualifications and experience; 2) 4.2 and 4.5 shed light on what they do on a day-to-day basis at work, differentiated by GISc registration category; and 3) 4.4 provides insight on motivators and barriers for registration. A conclusion and discussion of potential future follow-up research is provided in section 5 .

\section{Related work}

The article length limitations unfortunately do not allow a lengthy discussion of similar survey results in other countries. However, a few recent and on-going initiatives in the US and Europe are relevant.

The new Geomatics Profession Act 19 of 2013 identifies four registration categories in the geomatics profession: 1) candidate geomatics practitioner; 2) geomatics technician; 3) geomatics technologist; and 4) geomatics professional. The Act also identifies a number of branches (specialization field of geomatics), including land surveying, topographical surveying, engineering surveying, mine surveying, geo-spatial information science, hydrographic surveying and photogrammetric surveying; additional branches may be specified by the Minister. Registration categories differ based on the level of qualification, the requirements for practical training and the competency assessment. Except for professional land surveyors, the Act does not prescribe the type of work to be performed by the different categories and/or branches. However, the Act makes provision for the Minister to identify and prescribe geomatics work to be reserved for each category and branch.

The US Department of Labor Employment and Training Administration (DOLETA) has defined occupations in the field of geospatial technology, six of them are listed in Table 1. DOLETA defines occupations for cartography and mapping, as well as remote sensing, whereas in South Africa these fields of specialization are currently included in a single PLATO GISc branch. 
In comparison to the new Geomatics Profession Act 19 of 2013, the DOLETA occupations do not distinguish between a technologist and a professional; but the occupation descriptions differentiate between the type of work performed by GIS technicians and the type of work performed by geospatial information scientists and technologists. Further, the Geomatics Profession Act names four registration categories but does not specify the type of work performed (or to be performed) by GISc professionals registered in different categories. This survey aims to provide a better understanding of the type of work performed by GISc professionals of different registration categories.

Table 1. Occupations identified by the US Department of Labor Employment and Training Administration (DOLETA) in the field geospatial technology (DOLETA 2014)

\begin{tabular}{ll}
\hline \multicolumn{1}{c}{ Occupation } & \multicolumn{1}{c}{ Description } \\
\hline $\begin{array}{l}\text { Geospatial information } \\
\text { scientists and technologists }\end{array}$ & $\begin{array}{l}\text { Research or develop geospatial technologies. May produce databases, perform } \\
\text { applications programming, or coordinate projects. May specialize in areas such as } \\
\text { agriculture, mining, health care, retail trade, urban planning, or military intelligence. }\end{array}$ \\
\hline $\begin{array}{l}\text { Geographic information } \\
\text { system technicians }\end{array}$ & $\begin{array}{l}\text { Assist scientists, technologists, or related professionals in building, maintaining, } \\
\text { modifying, or using geographic information systems (GIS) databases. May also perform } \\
\text { some custom application development or provide user support. }\end{array}$ \\
\hline $\begin{array}{l}\text { Cartographers and } \\
\text { photogrammetrists }\end{array}$ & $\begin{array}{l}\text { Collect, analyze, and interpret geographic information provided by geodetic surveys, } \\
\text { aerial photographs, and satellite data. Research, study, and prepare maps and other } \\
\text { spatial data in digital or graphic form for legal, social, political, educational, and design } \\
\text { purposes. May work with Geographic Information Systems (GIS). May design and } \\
\text { evaluate algorithms, data structures, and user interfaces for GIS and mapping systems. }\end{array}$ \\
\hline Mapping technicians & $\begin{array}{l}\text { Calculate mapmaking information from field notes, and draw and verify accuracy of } \\
\text { topographical maps. }\end{array}$ \\
\hline Remote sensing scientists & $\begin{array}{l}\text { Apply remote sensing principles and methods to analyze data and solve problems in } \\
\text { areas such as natural resource management, urban planning, or homeland security. May } \\
\text { develop new sensor systems, analytical techniques, or new applications for existing } \\
\text { systems. }\end{array}$ \\
\hline Remote sensing technicians & $\begin{array}{l}\text { Apply remote sensing technologies to assist scientists in areas such as natural resources, } \\
\text { urban planning, or homeland security. May prepare flight plans or sensor configurations } \\
\text { for flight trips. }\end{array}$ \\
\hline
\end{tabular}

A study of European micro, small and medium-sized enterprises (SME) in the Geo-ICT sector (i.e. companies involved in the creation and publishing of spatial data and more traditional GIS/geolocation based activities) concluded in 2013 that SMEs in the Geo-ICT sector are active in many different fields and carry out all kinds of activities: data collection, data integration and processing, consultancy and service provision, application development, research and training, etc. (Cipriano et al. 2013). The study found that the Geo-ICT sector mainly consists of medium-sized and especially small enterprises. Apart from these, in most countries larger ICT companies with a small Geo-ICT division are also providing Geo-ICT products and services. The study estimated that Geo-ICT companies comprise 1-2\% of the overall ICT sector in Europe (Cipriano et al. 2013).

A current project in Europe (www.gi-n2k.eu) aims to match GISc education and vocational training to requirements in the job market. This is similar to the survey presented in this article, however, results from the European project are not yet available. 


\section{Methodology}

The purpose of the survey was 'to get a better understanding of who the members of the South African geoinformation community are and what they do on a day-to-day basis at work'. The survey used the term 'geoinformation community' as it appears in GISSA's mission statement. However, the term 'GISc community' is more widely used and therefore also used in this article.

An online questionnaire (hosted on the GISSA website) was distributed to 2,250 email addresses registered on the GISSA website (most, but not all, are members of GISSA). Responses were analysed. The questionnaire was structured into five sections, each investigating a different aspect of the South African GISc community:

1. What are the demographics of the South African GISc community?

2. Where are its members employed?

3. What are the qualifications and experience of its members?

4. Are members of the GISc community registered with PLATO or another professional body? If not, what are the barriers to registration?

5. What do its member do on a daily basis at work?

The questions posed in these sections contribute to understanding the demand and supply for GISc skills and knowledge with reference to the PLATO GISc registration categories and the type of work performed by GISc professionals on a daily basis.

The authors prepared a first draft questionnaire in SurveyMonkey (www.surveymonkey.com). Feedback on this questionnaire was obtained from a number of representatives of the GISc community who were invited to a workshop by GISSA. The online questionnaire was revised and made available on the GISSA website (www.gissa.org.za/activities/gissa-survey) for a period of three months from early November 2013 to early February 2014. Invitations to complete the survey were distributed via e-mail to the approximately 2,250 GISSA members.

\section{Survey results}

\subsection{Demographics of the respondents}

$750(33 \%)$ of the approximately 2,250 email recipients started the questionnaire and $626(28 \%)$ completed the questionnaire. The quantitative analysis in this article is based on the 626 completed questionnaires and 'respondents' from now on refers to those who completed the questionnaire (i.e. incomplete questionnaires are not included in the analysis). According to the PLATO website (www.plato.org.za), in February 2014 there were 548 registered GISc professionals in South Africa in the three GISc registration categories (practitioner, technologist and technician). Of these, 202 ( $37 \%$ ) completed the questionnaire. These response rates indicate that the survey sample and consequently also the survey results are representative of the South African GISc community. 
Figure 1 shows that gender and population group transformation are well underway but do not (yet) correlate with the demographics of South Africa's population reported by Stats SA (2012a) as: Male 49\% and Female 51\%; Black African 80\%, Coloured 9\%, Indian/Asian 3\% and White 9\%.
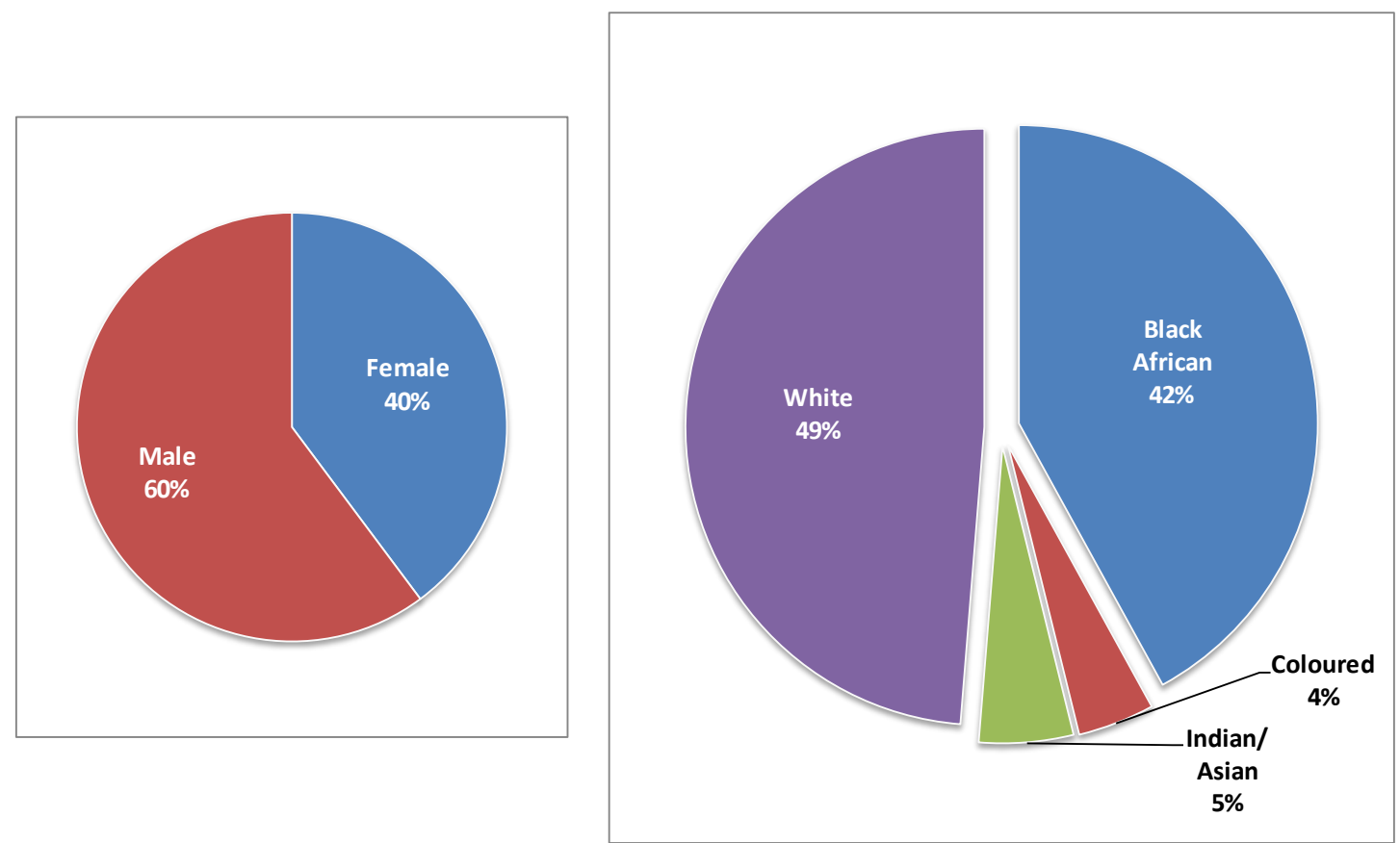

Figure 1. Gender and population group of respondents

The age distribution of respondents, illustrated in Figure 2, shows a sharp drop below the age of 25. This can be attributed to the fact that people in South Africa typically complete a three- or fouryear Bachelors degree around the age of 21 or 22 and enter the job market after that. Most respondents fall into the 30-39 age group with a decline in respondents in older age groups. This pattern correlates with labour force participation rates in South Africa (Stats SA 2012a, 2014).

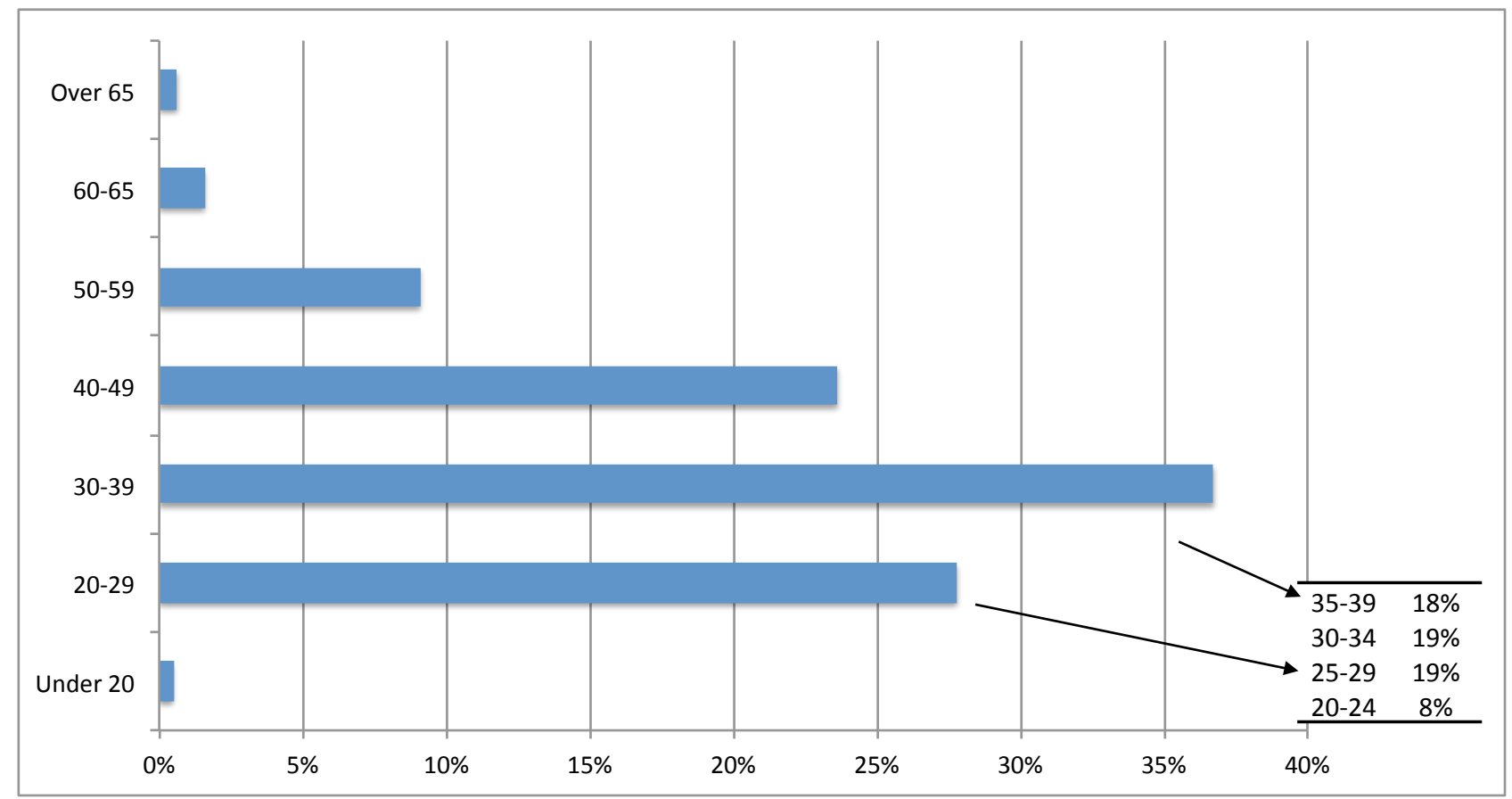

Figure 2. Age of respondents. Percentages for five year intervals of the 20-29 and 30-39 age groups are shown on the right. 


\subsection{Employment in the GISc community}

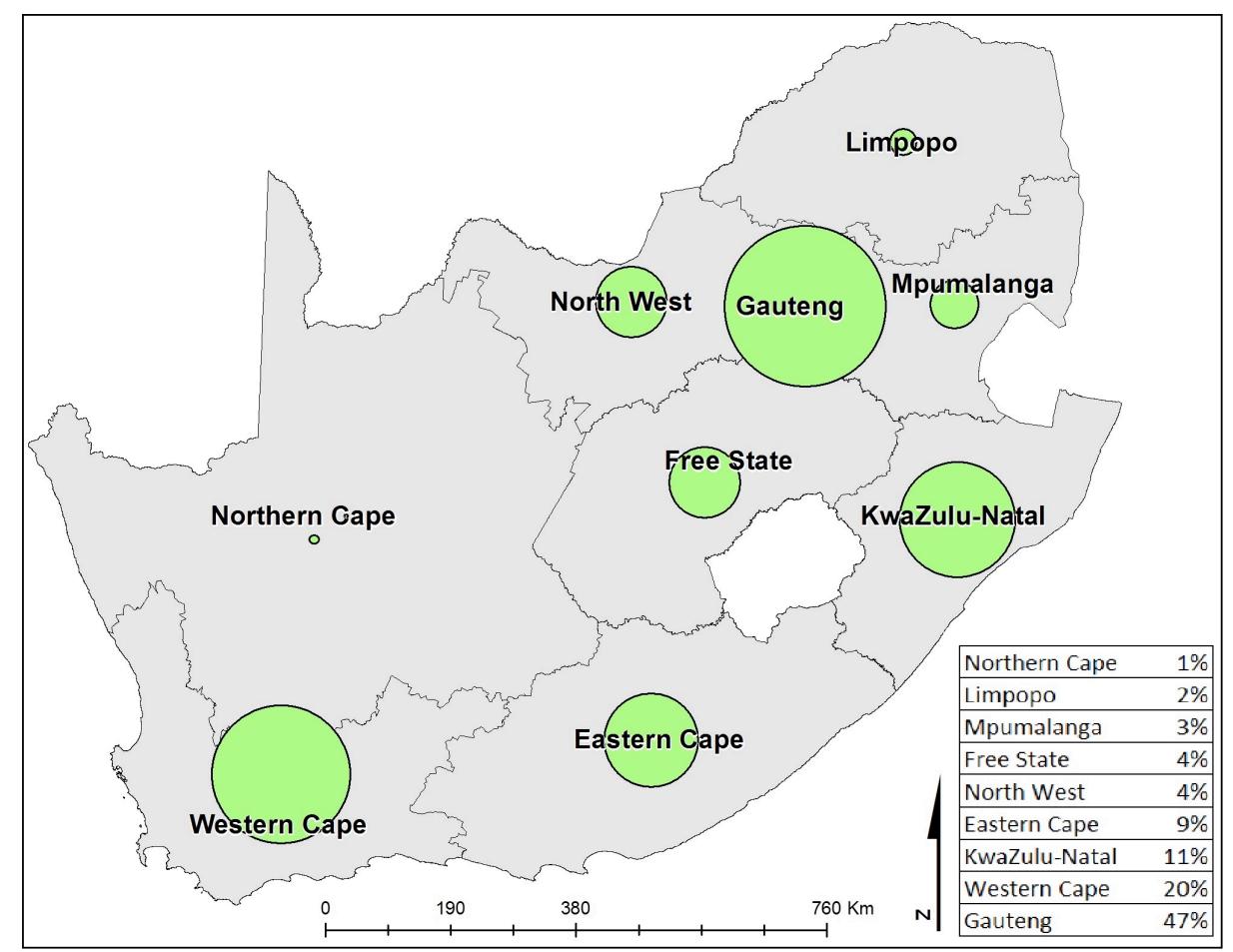

Figure 3. Locations of the primary office of respondents

The distribution of primary office locations of respondents is shown in the map in Figure 3. There are no surprises: the primary office of most respondents is in Gauteng, the economic hub of the country in which the administrative capital, Pretoria, is situated. The four provinces where most respondents have a primary office have the highest population sizes in South Africa: Eastern Cape, Gauteng, KwaZulu-Natal and Western Cape. Three of these (Gauteng, KwaZulu-Natal and Western Cape) contribute to more than $60 \%$ of the country's Gross Domestic Product (GDP) (Stats SA 2012b). The primary office distributions of respondents in the public and private sector are similar, i.e. in both cases most are in Gauteng, followed by the Western Cape, KwaZulu-Natal and the Eastern Cape.

The graphs in Figure 4 show the economic sector of employers and area of jurisdiction of public sector employers respectively. The age distribution of respondents in each economic sector largely resembles the age distribution of all respondents (see 3.1), except academia and research with comparatively higher percentages of employees under the age of 30 . These higher percentages probably reflect MSc- and $\mathrm{PhD}$ students employed by universities and science councils during their studies.

$17 \%$ of respondents were from eight metropolitan municipalities, while another $17 \%$ of respondents were from 226 local municipalities and 44 district municipalities - comparatively, the number of respondents from the local and district municipalities is low. Simple statistics suggest that the demand for GISc skills and services in 226 local municipalities and 44 district municipalities should be higher than in eight metropolitan municipalities - even if the demand in a local municipality is smaller than in a metropolitan municipality. The low number could be a 
reflection of the general skills shortage at local municipalities or of a lack of awareness of the value and need for GISc skills. It could also be a reflection of a higher representation of the metropolitan GISc community among respondents. Further investigation into the demand for GISc knowledge and skills in different regions and sectors of South Africa is required to clarify this.

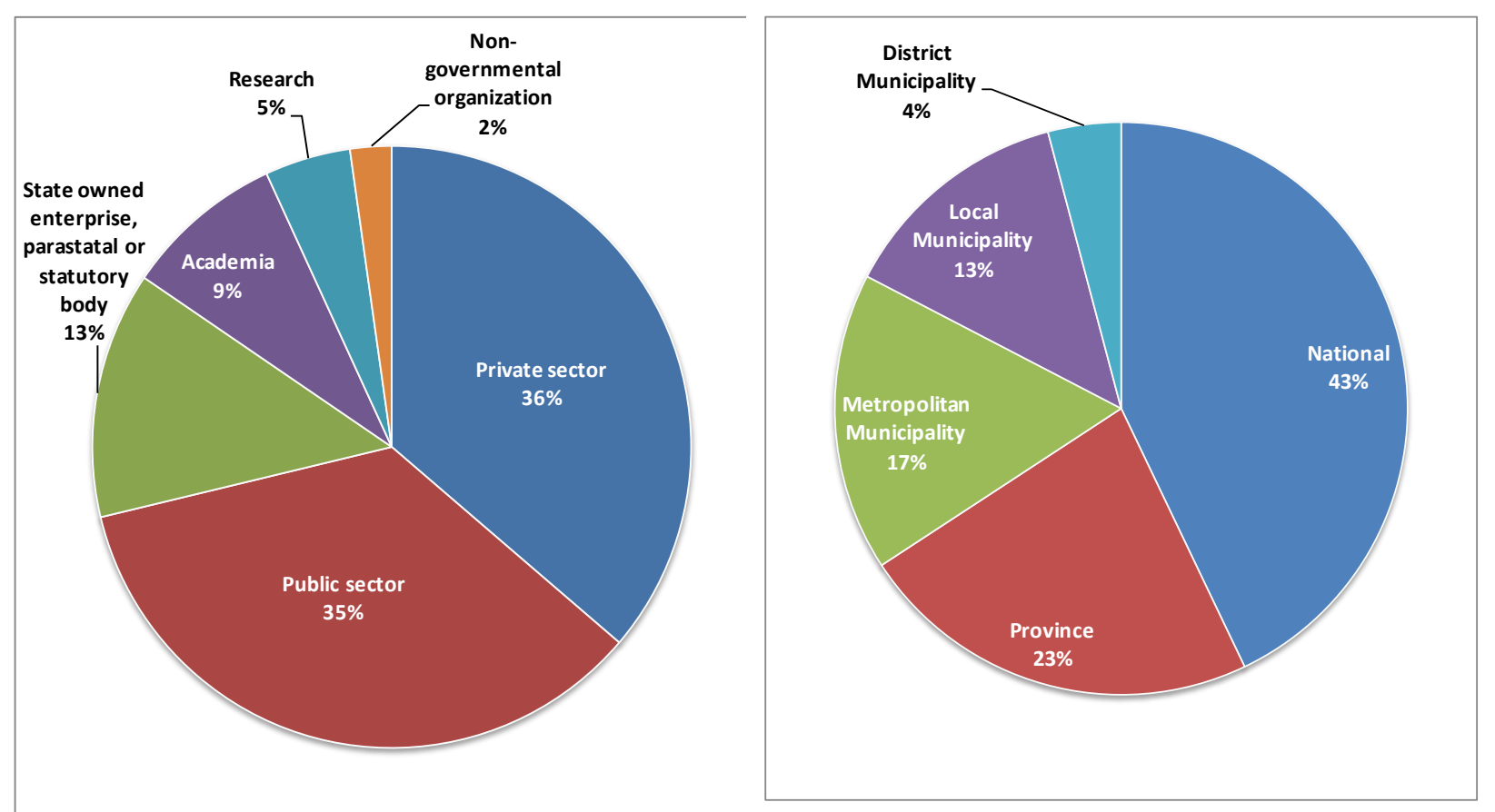

Figure 4. Economic sector of employers (left) and area of jurisdiction (right) of public sector employers of respondents

Table 2. Industries, application areas and disciplines in which respondents work (sorted by number of respondents)

\begin{tabular}{lc}
\hline \multicolumn{1}{c}{ Industry } & Percentage of respondents \\
\hline Environmental & $31 \%$ \\
\hline Information Technology & $23 \%$ \\
\hline Urban and regional planning & $19 \%$ \\
\hline Other (please specify) & $17 \%$ \\
\hline Water Resources & $16 \%$ \\
\hline Agriculture & $15 \%$ \\
\hline Surveying & $15 \%$ \\
\hline Land Administration & $14 \%$ \\
\hline Public Utilities & $14 \%$ \\
\hline Conservation & $13 \%$ \\
\hline Education & $13 \%$ \\
\hline Mining & $12 \%$ \\
\hline Demographic Surveys & $12 \%$ \\
\hline Transport and Traffic & $10 \%$ \\
\hline Items checked by less than $10 \%$ of respondents & $70 \%$ \\
\hline
\end{tabular}


Table 2 shows the industries, application areas and disciplines in which respondents mainly work. Respondents were asked to select one or more of these from a list. Most respondents selected 'Environmental' (31\%), 'Information Technology' (23\%) and 'Urban and regional planning' (19\%). Most respondents checked one (16\%), two (12\%), three $(10 \%)$ or four $(14 \%)$ items in the list, suggesting that respondents tend to focus on a limited number of industries, application areas and disciplines in their work. $70 \%$ of respondents selected the following items not listed in Table 2: Energy, Housing, Disaster and Emergency Management, Construction, Climate change, Health Services, Telecommunication, Business/Marketing, Defense Intelligence, Social Welfare, Law enforcement, Banking, Retail, Statistics, Insurance, Advertising. Their response percentage is shown in the last row of Table 2. The fact that each industry in the list was selected by at least four respondents implies that the GISc community of South Africa is active in a wide range of application areas.

\subsection{Qualifications and experience of respondents}

Most respondents have a 4-year degree or equivalent (including an Honours degree), see Figure 5. This corresponds to the qualification level required for registration as a GISc practitioner. The 3year degree or equivalent corresponds to the qualification level required for registration as a GISc technologist, while the 3-year diploma or equivalent corresponds to the qualification level required for registration as a GISc technician. Most respondents (74\%) have higher qualifications in Geoinformatics/GISc/Geomatics (23\%), Geography (18\%), Environmental Science (13\%), Remote sensing $(10 \%)$ or Computer Science/IT (10\%). These disciplines correspond well to the most prominent industries, application areas and disciplines (Environmental, Information Technology, Urban and regional planning) in which respondents work (compare Table 2).

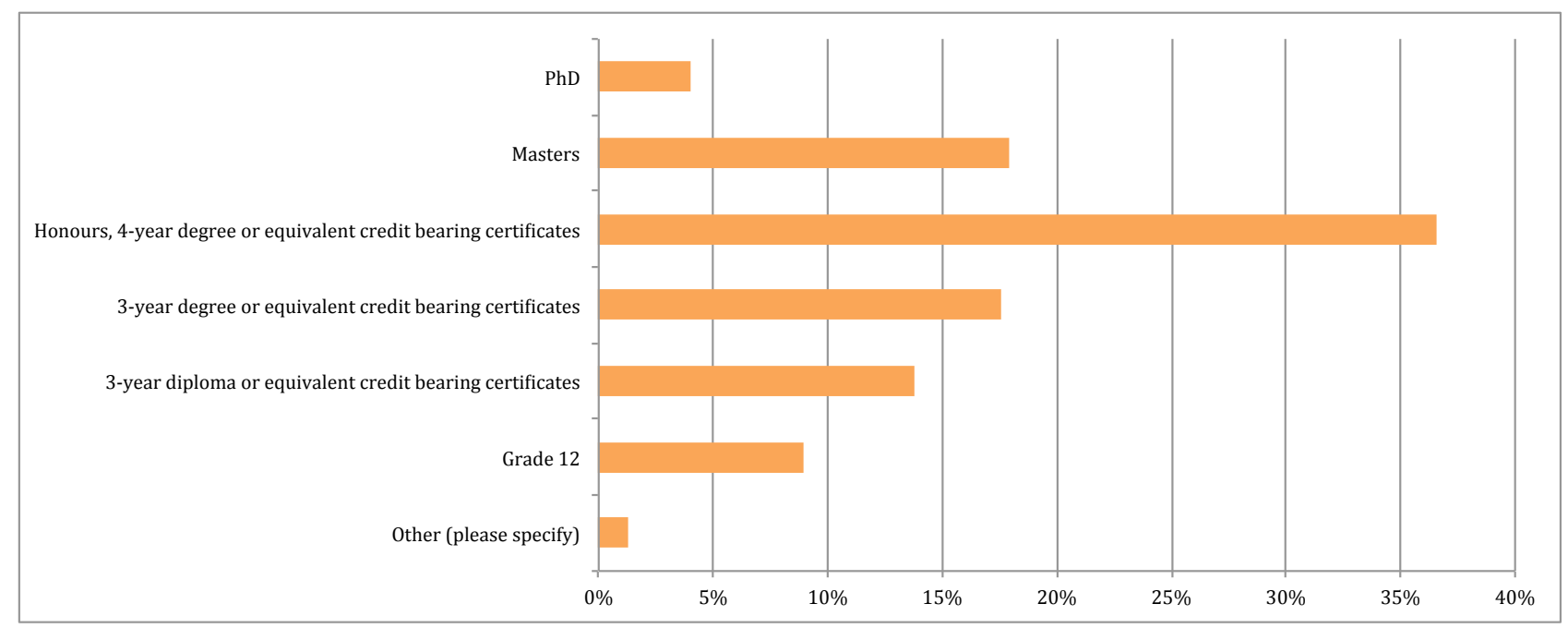

Figure 5. Highest qualification of respondents

The statistics in Figure 5 reflect a well-educated GISc community in which the majority of members have post-school qualification. However, the statistics are a concern if one assumes that those with a higher qualification usually perform either the role of project manager who guides others to do the bulk of work (e.g. data capturing), or the role of the specialist who is restricted to 
highly specialized technical work. One can attempt to explain the statistics in various ways. For example, the data capturers might not have completed the survey because they do not consider themselves to be part of the GISc community. Alternatively, the statistics could imply that data capturers in South Africa are over-qualified. A more in-depth investigation is required to better understand the skewed statistics.

The age distribution of respondents reveals that $40 \%$ of respondents under the age of 40 have at least an Honours, four-year degree or equivalent. That is, the level of the highest qualification of members under 40 corresponds to the level required for registration as GISc practitioner. Roughly every second respondent under the age of 40 has at least a 3-year degree or equivalent.

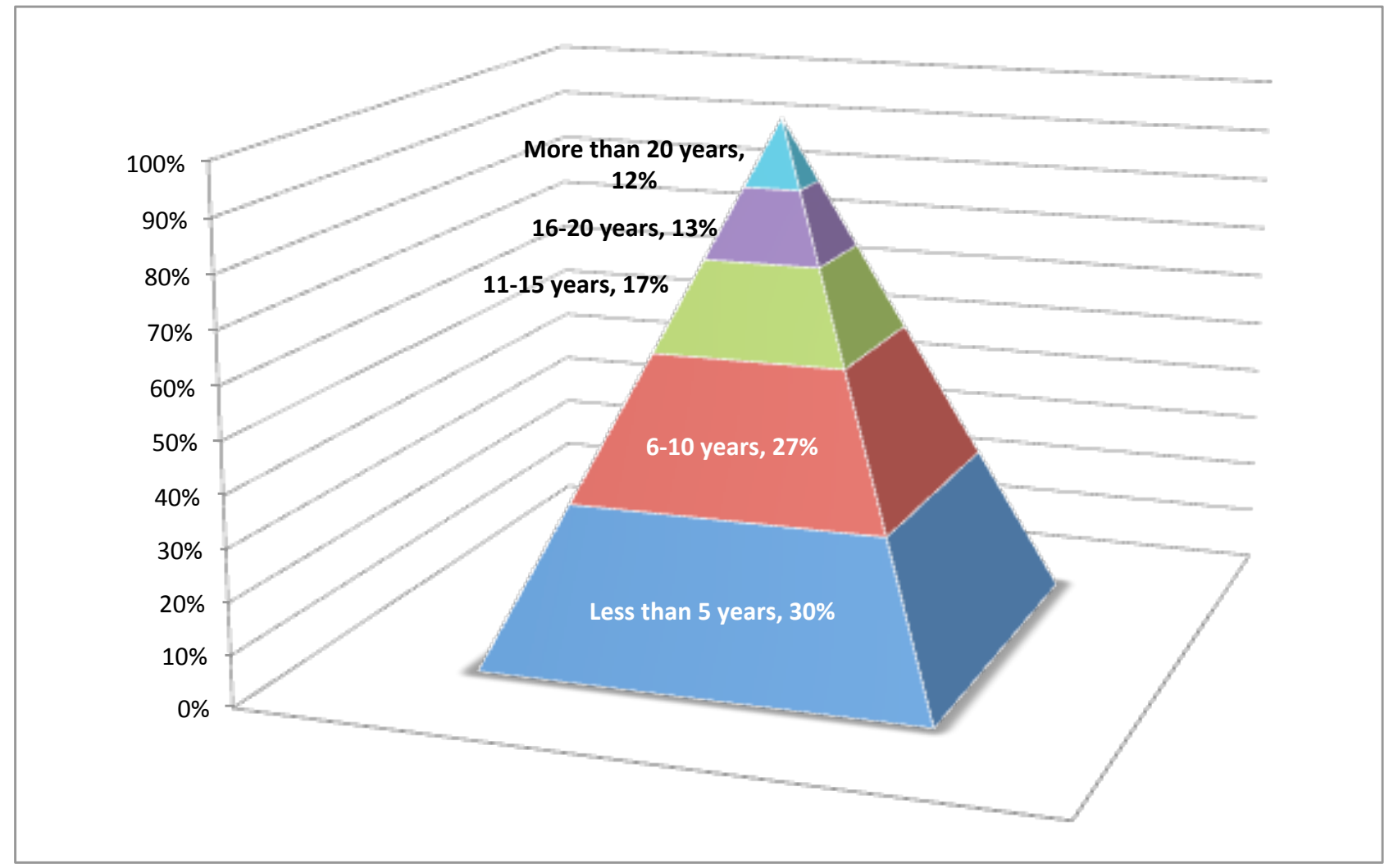

Figure 6. Years of experience of respondents in GISc related work

The number of years experience in GISc related work resembles a 'healthy' pyramid, see Figure 6. The number of years experience is inversely proportional to the percentage of respondents and correlates with the age of respondents: older respondents have more experience. Among the respondents over 40 years of age, 30\% have 6-10 years of experience and $11 \%$ have less than five years experience. This amounts to roughly a quarter of all respondents switching to GISc related work later in their career.

\subsection{Professional registration status of respondents}

Less than half of the respondents (40\%) are registered with a professional body. Most of these respondents $(57 \%)$ registered because it was required for their jobs. Pressure from their employer (25\%) and social status at work (24\%) are also motivating factors; tender requirements (11\%) and status in the community (9\%) are less important. Predominantly, respondents are registered with 
PLATO. See Figure 7. In the GISc category, the distribution among practitioners, technologists and technicians is more or less equal. See Figure 8.

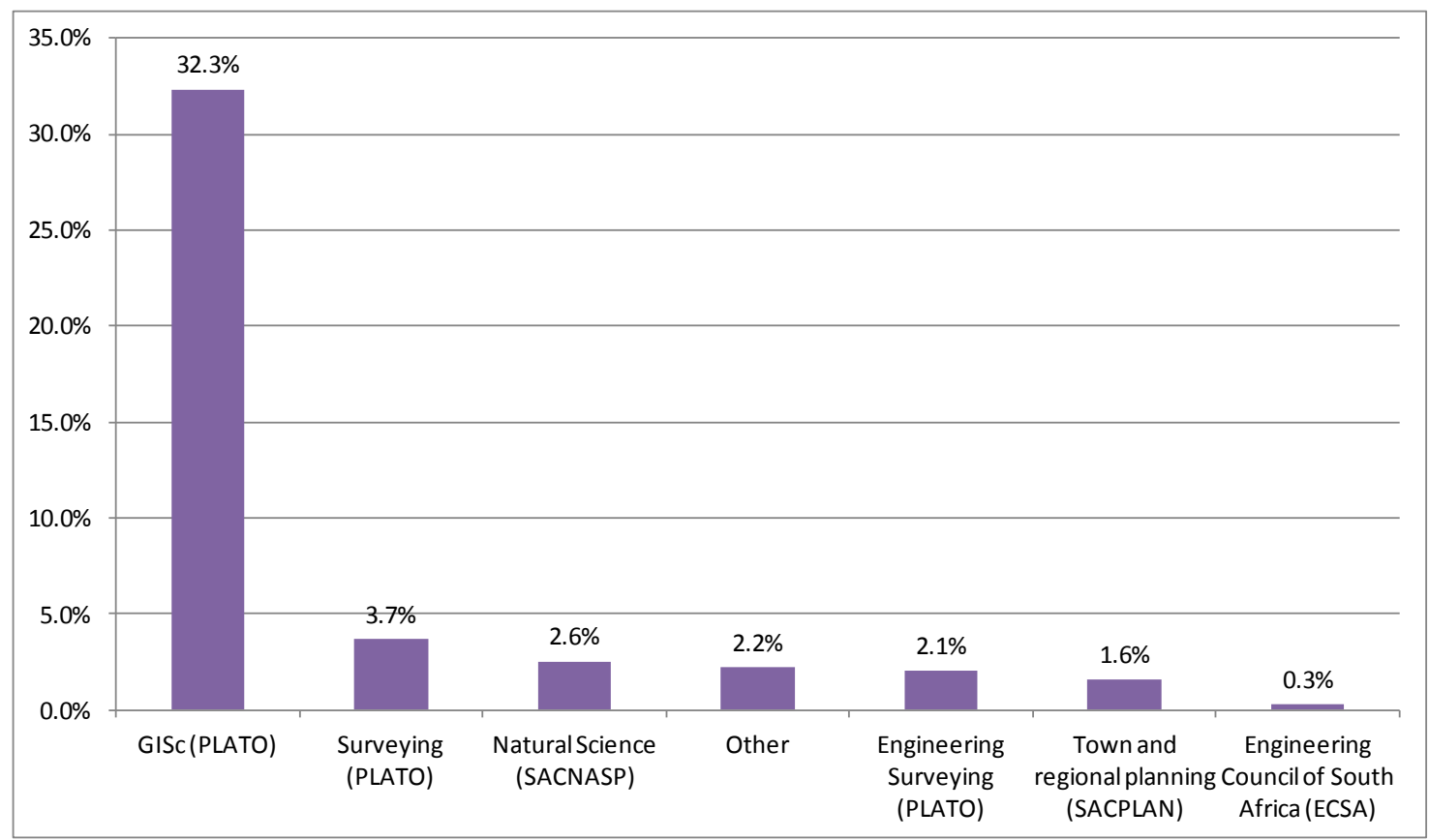

Figure 7. Professional bodies where respondents are registered

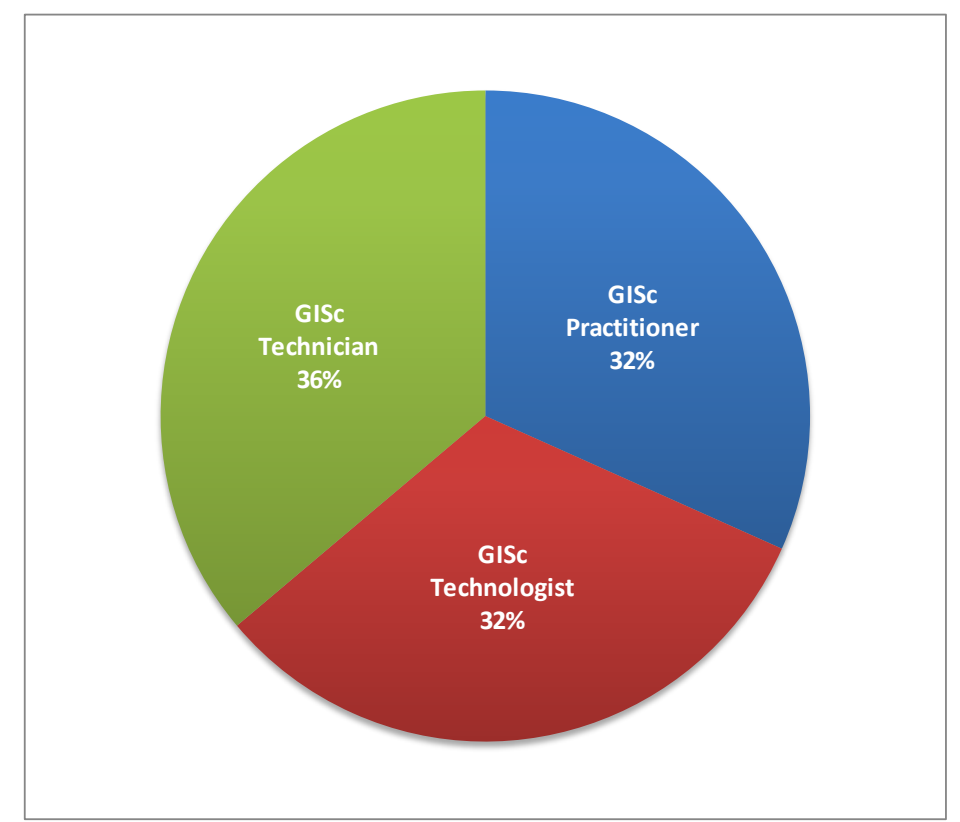

Figure 8. PLATO GISc registration categories of respondents

Roughly $40 \%$ of respondents who are not registered seem to have an appropriate qualification. They could have enough experience to meet registration requirements, but the 'Less than 5 years' category is too vague to be sure about this. Most of them are also under the age of 40, implying that they still have a considerable number of years of employment ahead of them, making registration with a professional body worthwhile for their careers. See Figures 9 and 10. 

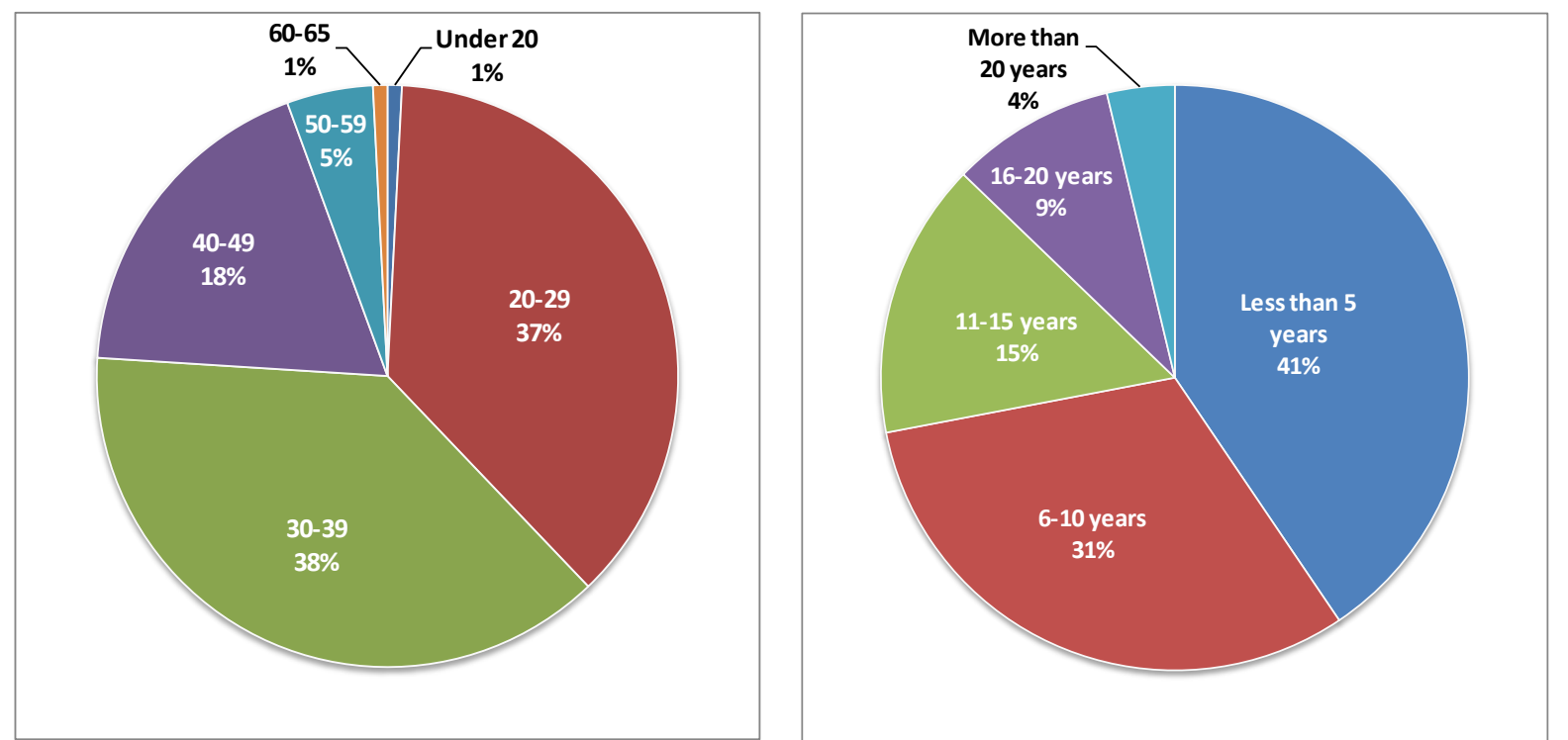

Figure 9. Respondents who are not registered with a professional body: age distribution (left), years of experience (right)

Closer inspection of the reasons why these respondents are not registered provides insight into the barriers to professional GISc registration. 33\% of unregistered respondents were not interested in professional registration and/or indicated that it is not required for their work. It is to be expected that a certain percentage of the GISc community will always remain unregistered. This percentage will only shrink if certain work is reserved for registered GISc professionals (currently not the case).

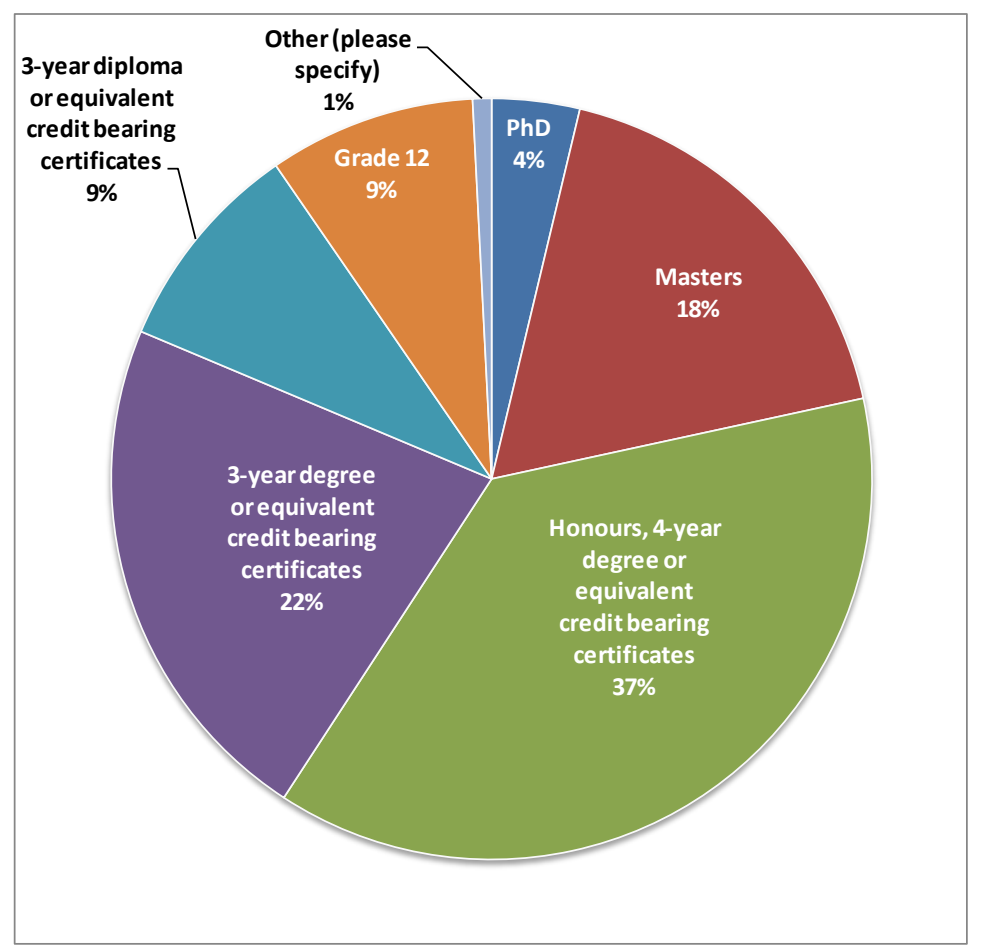

Figure 10. Respondents who are not registered with a professional body: highest qualification $26 \%$ of unregistered respondents indicated that their qualifications do not meet the academic requirements for professional registration. Among these, $73 \%$ have a tertiary qualification, suggesting that the level of qualification is not the problem, but rather the adequacy, i.e. the specific 
content of the qualification does not meet the requirements. For example, respondents might have a related qualification (e.g. BA Geography or BSc Geography) that meets many or most of the PLATO requirements but not all of them. Alternatively, respondents might have completed a qualification in a different discipline before starting to work in the GISc industry.

These statistics can be explained by the fact that accreditation of GISc programmes offered at South African universities commenced as late as 2012. As a result, the majority of people working in the GISc field obtained their qualifications before GISc programmes were accredited. Options for acquiring additional GISc skills and knowledge in a part-time and/or piecemeal fashion or through distance learning are limited. One exception is the course in GIS professional practice presented through CE at UP. The course covers the PLATO academic requirements for the GIS professional practice theme, a typical gap in a technical or scientific (as opposed to professional) qualification. An analysis of PLATO registration application statistics could shed further light on prominent gaps in applicants' qualifications. Results could assist universities and training institutions in designing courses that address these gaps.

$22 \%$ of unregistered respondents indicated that they had missed the Grandfather clause. There was another opportunity to register under the Grandfather clause. The deadline was in April 2014 (after the survey had closed). Hopefully, some of these respondents used the opportunity to get registered. $20 \%$ of unregistered respondents do not know what to do to get professional registration. This calls for (even more) awareness and information dissemination from the professional bodies. It could also indicate disinterest in registration because advice on how to register is freely available on the GISSA website (www.gissa.org.za) and legal registration requirements are published on the PLATO website (www.plato.org.za). Finally, 14\% of unregistered respondents have submitted their application for registration and were awaiting a response at the time of the survey.

\subsection{Daily work}

The last part of the questionnaire was aimed at understanding the day-to-day work of the GISc community. Firstly, respondents were asked which roles they mainly perform in their current job (they could select a maximum of three roles). Data analysis and interpretation (20\%), followed by data acquisition (12\%), visualization/mapping (12\%) and data management (11\%) are most common. See Figure 11 (top). The other graphs in Figure 11 show that the composition of roles differs for the different registration statuses. GISc practitioners typically spend most of their time on data analysis and interpretation (19\%), management (15\%), project management (14\%) and data management (10\%); GISc technologists spend time on a larger variety of tasks, namely, data analysis and interpretation (20\%), data acquisition (10\%), management (10\%), data management (10\%) and visualization/mapping (10\%); and GISc technicians spend most of their time on data analysis and interpretation (23\%), visualization/mapping (16\%), data acquisition (15\%) and data management $(15 \%)$. 
South African Journal of Geomatics, Vol. 3, No.2, August 2014
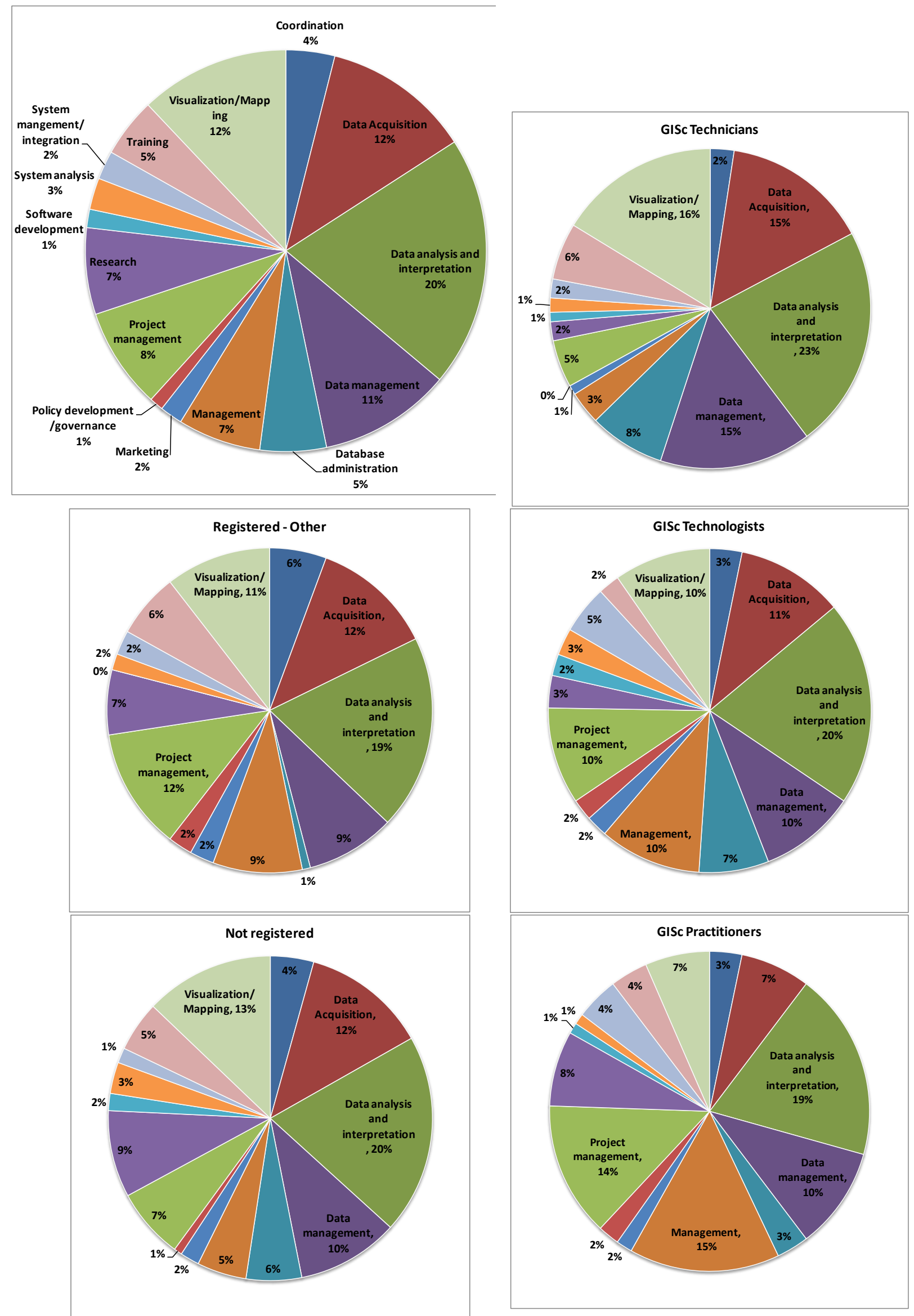

Figure 11. Roles performed by respondents in their current job 
Interestingly, for all three levels data analysis and interpretation is most frequently reported to be part of their day-to-day work; project management and management show a downward trend from GISc practitioner to GISc technologist and GISc technician, while data acquisition and visualization/mapping show an upward trend from GISc practitioner to GISc technologist and GISc technician. That is, project management and management are typically performed by GISc practitioners, while data acquisition and visualization/mapping are typically performed by GISc technicians. GISc technologists seem to be 'jacks-of-all-trades': apart from data analysis and interpretation, the other roles are equally distributed among respondents. In comparison to the other groups, more GISc technologists spend time on system analysis, system integration and management, marketing and software development than any of the other groups.

In Figure 12 the main roles performed by respondents of different registration categories in their daily work are compared against each other. For example, 64\% of the GISc Technicians who responded indicated that data analysis and interpretation (i.e. extract information to derive conclusions and inform decision-making) is one of the roles they mainly perform in their daily work. Figure 12 confirms that GISc practitioners, as well as respondents registered with other professional bodies, tend to focus on management and project management. Data analysis and interpretation, visualization and mapping, data acquisition and data management make up a large part of the work of both GISc technicians and unregistered respondents. The question is whether these high percentages represent people from other disciplines who use GIS as a tool and whose qualifications do not meet the academic requirements of the PLATO GISc academic model (even though they might have postgraduate degrees)? Further investigation is required to answer this question.

These results raise many questions: What roles should people with different registration categories actually be performing in their daily work? Is the distinction between types of work for different registration categories clear enough? Is a separate registration category required for people from other disciplines who spend a considerable amount of time using GIS as a tool?

Secondly, respondents were asked to indicate which GISc knowledge and skills they use at least once a month to do their work. The list of GISc knowledge and skills is a combination of knowledge areas from the UCGIS BoK (DiBiase et al. 2006) and themes from the PLATO academic model. Results are shown in Figure 13, Figure 14 and Table 3. Programming, mathematics and physics stand out in Figure 13 because many respondents indicated that they do not need them on a day-to-day basis. These results concur with results reported by Du Plessis and Van Niekerk (2014) where GISc experts rated physics least important among 16 knowledge areas in a prototype GISc framework. However, research into GISc competency requirements confirms the need to include these 'basic' sciences in academic qualifications. 
South African Journal of Geomatics, Vol. 3, No.2, August 2014
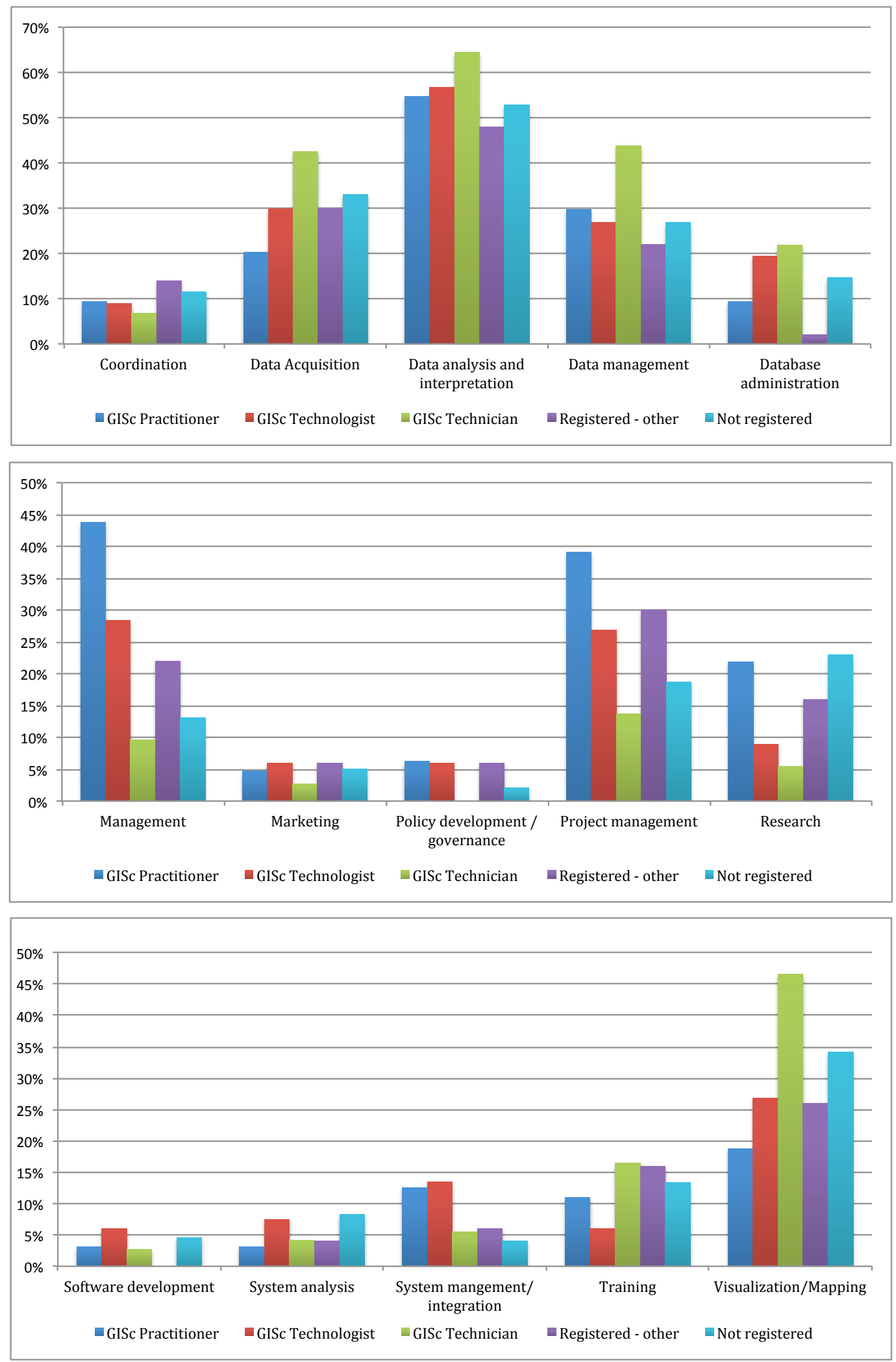

Figure 12. Roles performed by respondents with different registration statuses in their current job 


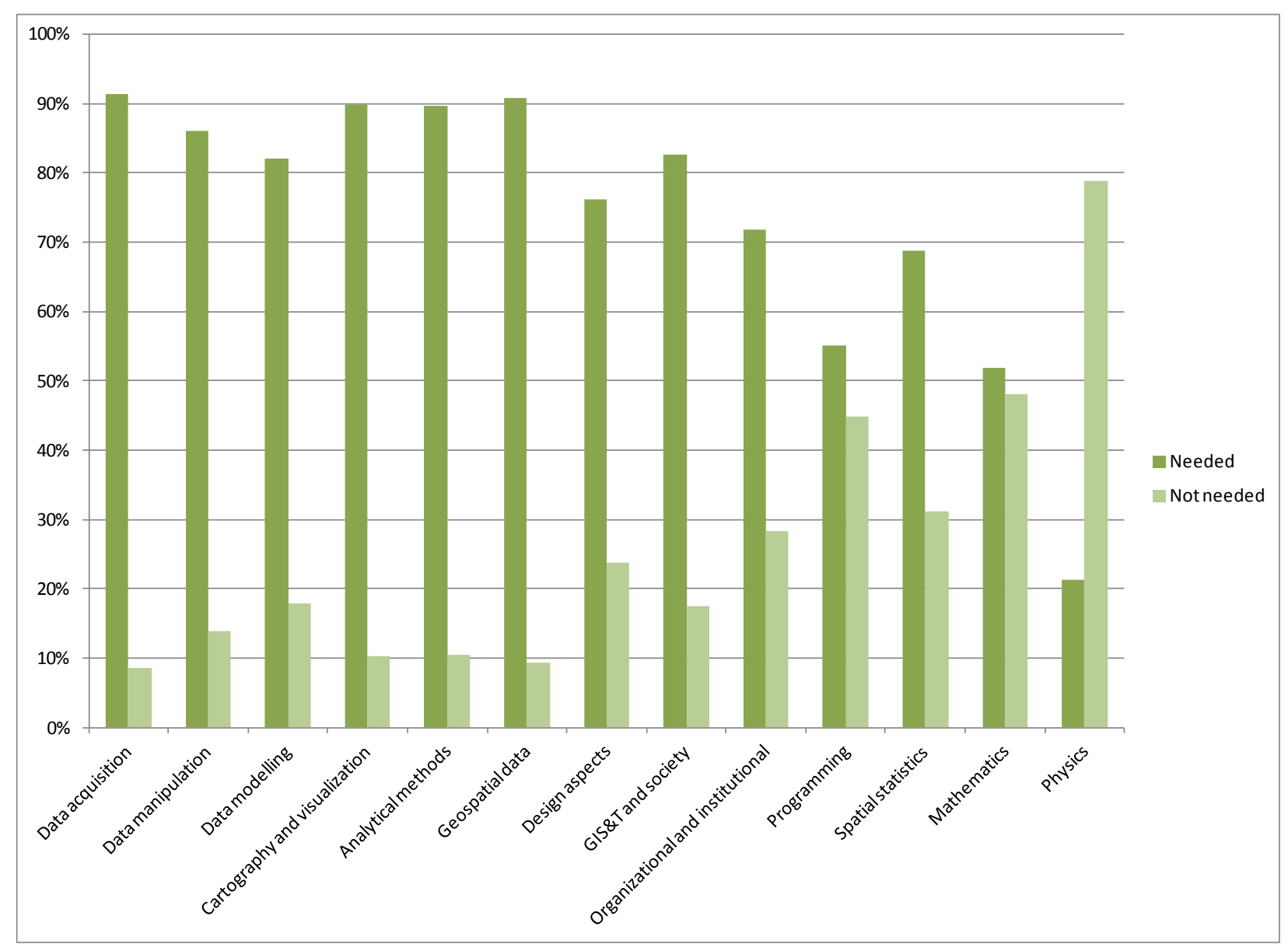

Figure 13. GISc knowledge and skills used at least once a month by respondents

Figure 14 shows that respondents attribute more or less equal weightings to most of the skills they need, with physics, mathematics and programming rated lowest. Interestingly, the distribution of skills shown in Figure 14 is similar for the five individual registration statuses (i.e. GISc practitioner, GISc technologist, GISc technician, registered with another professional body and those not registered).

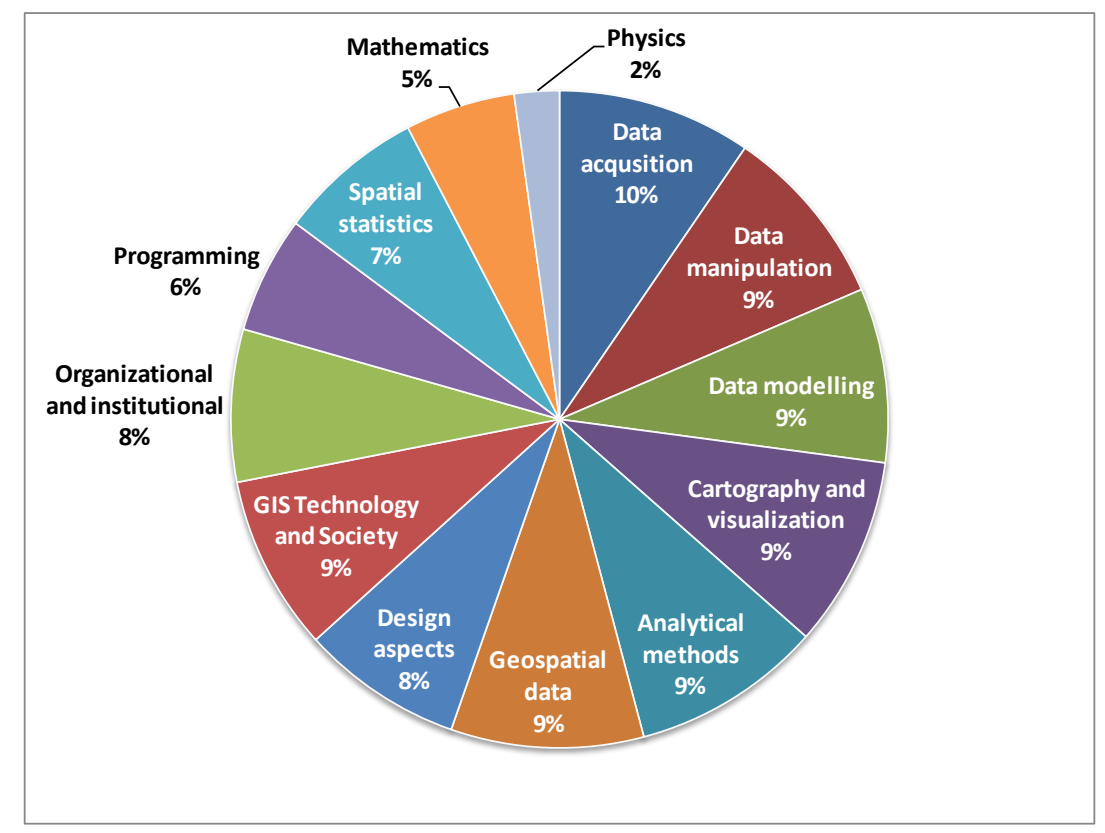

Figure 14. Distribution of GISc knowledge and skills applied at least once a month 
Table 3 lists the top three skills used by all respondents, by GISc practitioners, by GISc technologists and by GISc technicians at least once a month to do their work. Significant differences between the top three skills in the four groups are in bold. Among these, the most interesting is that people registered with PLATO in one of the GISc categories perform raster classifications less frequently than the remainder of respondents. Closer inspection shows that people registered with other professional bodies do some raster classification, but a significant number of unregistered people do raster classification at least once a month. This is an important finding, as it suggests that people with remote sensing skills are currently excluded from GISc registration with PLATO. Further research is required to better understand why they are not registered with PLATO and whether an additional branch for remote sensing should be specified through the Geomatics Profession Act.

Table 3. Top three GISc knowledge and skills applied at least once a month

\begin{tabular}{|c|c|c|c|c|}
\hline \multirow{2}{*}{$\begin{array}{c}\text { GISc } \\
\text { knowledge and } \\
\text { skills }\end{array}$} & \multicolumn{4}{|c|}{ Top three tasks } \\
\hline & All respondents & GISc practitioners & GISc Technologists & GISc Technicians \\
\hline Data acquisition & $\begin{array}{l}\text { 1. Spatial and attribute } \\
\text { data transfer } \\
\text { between formats } \\
\text { 2. Manual input - data } \\
\text { capture } \\
\text { 3. Managing the } \\
\text { quality of collected } \\
\text { data }\end{array}$ & $\begin{array}{l}\text { 1. Spatial and attribute data } \\
\text { transfer between formats } \\
\text { 2. Managing the quality of } \\
\text { collected data } \\
\text { 3. Assess data quality; Data } \\
\text { migration and } \\
\text { manipulation }\end{array}$ & $\begin{array}{l}\text { 1. Spatial and attribute data } \\
\text { transfer between formats; } \\
\text { Managing the quality of } \\
\text { collected data } \\
\text { 2. Assess data quality; Data } \\
\text { migration and } \\
\text { manipulation }\end{array}$ & $\begin{array}{l}\text { 1. Manual input - data } \\
\text { capture } \\
\text { 2. Spatial and attribute } \\
\text { data transfer between } \\
\text { formats } \\
\text { 3. Digitising }\end{array}$ \\
\hline $\begin{array}{l}\text { Data } \\
\text { manipulation }\end{array}$ & $\begin{array}{l}\text { 1. Vector } \\
\text { classification (e.g. } \\
\text { thematic maps, hot- } \\
\text { spot mapping) } \\
\text { 2. Validation/Fixing } \\
\text { Geometry (Data } \\
\text { Cleaning) } \\
\text { 3. Raster } \\
\text { classification } \\
\text { (supervised and } \\
\text { unsupervised) }\end{array}$ & $\begin{array}{l}\text { 1. Vector classification } \\
\text { 2. Generalization, } \\
\text { aggregation or conflation } \\
\text { 3.Interpolation }\end{array}$ & $\begin{array}{l}\text { 1. Vector classification } \\
\text { 2. Validation/ Fixing } \\
\text { Geometry } \\
\text { 3. Generalization, } \\
\text { aggregation or conflation }\end{array}$ & $\begin{array}{l}\text { 1. Vector classification } \\
\text { 2. Validation/ Fixing } \\
\text { Geometry } \\
\text { 3. Generalization, } \\
\text { aggregation or } \\
\text { conflation }\end{array}$ \\
\hline Data modelling & $\begin{array}{l}\text { 1. Database } \\
\text { management } \\
\text { systems } \\
\text { 2. Basic storage and } \\
\text { retrieval structures } \\
\text { 3. Vector and object } \\
\text { data models }\end{array}$ & $\begin{array}{l}\text { 1.Database management } \\
\text { systems } \\
\text { 2. Basic storage and } \\
\text { retrieval structures } \\
\text { 3. Vector and object data } \\
\text { models }\end{array}$ & $\begin{array}{l}\text { 1. Database management } \\
\text { systems } \\
\text { 2. Basic storage and retrieval } \\
\text { structures } \\
\text { 3. Vector and object data } \\
\text { models }\end{array}$ & $\begin{array}{l}\text { 1. Database management } \\
\text { systems } \\
\text { 2. Basic storage and } \\
\text { retrieval structures } \\
\text { 3. Vector and object data } \\
\text { models }\end{array}$ \\
\hline $\begin{array}{l}\text { Cartography and } \\
\text { visualization }\end{array}$ & $\begin{array}{l}\text { 1. Map production } \\
\text { 2. Map use and } \\
\text { evaluation } \\
\text { 3. Raster backdrops; } \\
\text { Principles of map } \\
\text { design }\end{array}$ & $\begin{array}{l}\text { 1.Map production } \\
\text { 2.Raster backdrops } \\
\text { 3.Principles of map design }\end{array}$ & $\begin{array}{l}\text { 1. Map production } \\
\text { 2. Graphic representation } \\
\text { techniques } \\
\text { 3. Raster backdrops }\end{array}$ & $\begin{array}{l}\text { 1. Map production } \\
\text { 2. Raster backdrops } \\
\text { 3. Map use and evaluation }\end{array}$ \\
\hline $\begin{array}{l}\text { Analytical } \\
\text { methods }\end{array}$ & $\begin{array}{l}\text { 1. Basic analytical } \\
\text { methods (i.e. } \\
\text { Attribute Query, } \\
\text { Buffer Zone,etc.) } \\
\text { 2. Geometric } \\
\text { measures (i.e. Join, }\end{array}$ & $\begin{array}{l}\text { 1. Geometric measures } \\
\text { 2.Basic analytical methods } \\
\text { 3.Image interpretation }\end{array}$ & $\begin{array}{l}\text { 1. Basic analytical methods } \\
\text { 2. Geometric measures } \\
\text { 3. Query operations and } \\
\text { query languages }\end{array}$ & $\begin{array}{l}\text { 1. Basic analytical } \\
\text { methods } \\
\text { 2. Geometric measures } \\
\text { 3. Image interpretation }\end{array}$ \\
\hline
\end{tabular}




\begin{tabular}{|c|c|c|c|c|}
\hline \multirow{2}{*}{$\begin{array}{c}\text { GISc } \\
\begin{array}{c}\text { knowledge and } \\
\text { skills }\end{array} \\
\end{array}$} & \multicolumn{4}{|c|}{ Top three tasks } \\
\hline & All respondents & GISc practitioners & GISc Technologists & GISc Technicians \\
\hline & $\begin{array}{l}\text { Union, etc.) } \\
\text { 3. Image interpretation }\end{array}$ & & & \\
\hline Geospatial data & $\begin{array}{l}\text { 1. Projections } \\
\text { 2. Georeferencing } \\
\text { systems; Data } \\
\text { quality } \\
\text { 3. Datums }\end{array}$ & $\begin{array}{l}\text { 1.Projections } \\
\text { 2.Data quality } \\
\text { 3.Georeferencing systems }\end{array}$ & $\begin{array}{l}\text { 1. Data quality } \\
\text { 2. Projections } \\
\text { 3. Georeferencing systems }\end{array}$ & $\begin{array}{l}\text { 1. Projections } \\
\text { 2. Georeferencing systems } \\
\text { 3. Data quality }\end{array}$ \\
\hline Design aspects & $\begin{array}{l}\text { 1. Database design } \\
\text { 2. Analysis design } \\
\text { 3. Project definition }\end{array}$ & $\begin{array}{l}\text { 1.Database design } \\
\text { 2.Project definition } \\
\text { 3.Analysis design }\end{array}$ & $\begin{array}{l}\text { 1. Database design } \\
\text { 2. Project definition } \\
\text { 3. Analysis design }\end{array}$ & $\begin{array}{l}\text { 1. Database design } \\
\text { 2. Analysis design } \\
\text { 3. Project definition }\end{array}$ \\
\hline $\begin{array}{l}\text { Geospatial } \\
\text { information } \\
\text { systems, } \\
\text { technology and } \\
\text { society }\end{array}$ & $\begin{array}{l}\text { 1. Dissemination of } \\
\text { geospatial } \\
\text { information } \\
\text { 2. Critical GIS } \\
\text { 3. Use of geospatial } \\
\text { information in the } \\
\text { public sector }\end{array}$ & $\begin{array}{l}\text { 1.Dissemination of } \\
\text { geospatial information } \\
\text { 2.Use of geospatial } \\
\text { information in the public } \\
\text { sector } \\
\text { 3.Critical GIS; Ethical } \\
\text { aspects }\end{array}$ & $\begin{array}{l}\text { 1. Use of geospatial } \\
\text { information in the public } \\
\text { sector } \\
\text { 2. Dissemination of } \\
\text { geospatial information } \\
\text { 3. Critical GIS }\end{array}$ & $\begin{array}{l}\text { 1. Dissemination of } \\
\text { geospatial information } \\
\text { 2. Critical GIS } \\
\text { 3. Use of geospatial } \\
\text { information in the } \\
\text { public sector }\end{array}$ \\
\hline $\begin{array}{l}\text { Organizational } \\
\text { and institutional }\end{array}$ & $\begin{array}{l}\text { 1. GIS and technology } \\
\text { workforce themes } \\
\text { 2. Managing the GIS } \\
\text { operations and } \\
\text { infrastructure } \\
\text { 3. Organizational } \\
\text { structures and } \\
\text { procedures }\end{array}$ & $\begin{array}{l}\text { 1. Organizational structures } \\
\text { and procedures } \\
\text { 2. Managing the GIS } \\
\text { operations and } \\
\text { infrastructure } \\
\text { 3. Coordinating } \\
\text { organizations }\end{array}$ & $\begin{array}{l}\text { 1. Managing the GIS } \\
\text { operations and } \\
\text { infrastructure } \\
\text { 2. Organizational structures } \\
\text { and procedures } \\
\text { 3. GIS and technology } \\
\text { workforce themes }\end{array}$ & $\begin{array}{l}\text { 1. GIS and technology } \\
\text { workforce themes } \\
\text { 2. Managing the GIS } \\
\text { operations and } \\
\text { infrastructure } \\
\text { 3. Organizational } \\
\text { structures and } \\
\text { procedures }\end{array}$ \\
\hline Programming & $\begin{array}{l}\text { 1. Desktop software } \\
\text { development } \\
\text { 2. Internet mapping } \\
\text { 3. Web development }\end{array}$ & $\begin{array}{l}\text { 1.Internet mapping } \\
\text { 2.Desktop software } \\
\text { development } \\
\text { 3. Web development }\end{array}$ & $\begin{array}{l}\text { 1. Internet mapping } \\
\text { 2. Desktop software } \\
\text { development } \\
\text { 3. Web development }\end{array}$ & $\begin{array}{l}\text { 1. Desktop software } \\
\text { development } \\
\text { 2. Internet mapping } \\
\text { 3. Web development }\end{array}$ \\
\hline Spatial statistics & $\begin{array}{l}\text { 1. Sampling and } \\
\text { collection of data } \\
\text { 2. Geostatistics } \\
\text { 3. Descriptive } \\
\text { measures of } \\
\text { location and } \\
\text { dispersion }\end{array}$ & $\begin{array}{l}\text { 1. Sampling and collection } \\
\text { of data } \\
\text { 2. Geostatistics } \\
\text { 3. Descriptive measures of } \\
\text { location and dispersion }\end{array}$ & $\begin{array}{l}\text { 1. Sampling and collection of } \\
\text { data } \\
\text { 2. Network analysis } \\
\text { 3. Frequency distributions } \\
\text { and graphical } \\
\text { representations }\end{array}$ & $\begin{array}{l}\text { 1. Sampling and collection } \\
\text { of data } \\
\text { 2. Network analysis } \\
\text { 3. Geostatistics }\end{array}$ \\
\hline
\end{tabular}

Note: Mathematics and physics are not included.

\section{Conclusion}

The results of this survey shed light on who the members of the South African GISc community are. Gender representation in the GISc community is roughly equal, but population group representation does not correlate with South Africa's population. Age distribution among respondents correlates with labour force participation rates in South Africa.

Most respondents work in provinces with high economic activity, suggesting that there is higher demand for GISc knowledge and skills in these areas. However, the survey was not aimed at quantifying the demand for GISc knowledge and skills. Further investigation into the demand for GISc knowledge and skills in different regions and sectors of South Africa is required. 
While individual respondents tend to focus on a small number of industries, application areas and disciplines in their work, the GISc community of South Africa is active in a wide range of industries, application areas and disciplines. These range from 'traditional' application areas, such as spatial planning and environmental, to 'newer' application areas, such as advertising and insurance. Survey results suggest that roughly a quarter of all respondents switched to GISc related work later in their career.

The GISc community of South Africa is well-educated: $40 \%$ of respondents under the age of 40 have at least an Honours, four-year degree or equivalent credit bearing certificates. Roughly, every second respondent has at least a 3-year degree or equivalent credit bearing certificates. Nevertheless, qualifications that do not meet the requirements specified in the PLATO GISc academic model are a significant barrier to professional registration. An analysis of PLATO registration application statistics could shed further light on prominent gaps in applicants' qualifications and could inform universities and training institutions to design courses that address these gaps. However, one could ask whether the academic qualification criteria for professional registration are currently weighed too high in comparison to criteria related to practical training and competence assessment. Solutions for the assessment and recognition of prior learning in GISc have not been explored in South Africa. Further research is required to understand the reasons for the huge gap between respondents with and without at least a 3-year degree.

The results of this survey also show that most members of the GISc community fulfil roles of data analysis and interpretation, together with data acquisition, data management, and/or visualization/mapping. Many members reported that they did not need mathematics and physics on a daily basis. The Geomatics Profession Act 19 of 2013 only distinguishes between different registration categories based on academic qualification, practical training and competency assessments (clause 13. (5)). Differences in the type of work performed by different categories are not specified or prescribed. This survey has shed some light on how the daily work of people in different GISc registration categories differs, but further investigation is required to assess whether these differences are appropriate, i.e. do GISc practitioners, technologists and technicians do the work they are qualified for? And also: What should the differences be between the work performed by GISc practitioners, technologists and technicians respectively? Is an additional registration category required for professionals from other disciplines who use GIS as a tool? The job descriptions specified in the government's Occupation Specific Dispensation (OSD) (DPSA 2011) provide some guidance, but do not reflect work performed in the entire geospatial industry. The survey results further show that people with remote sensing skills are currently excluded from GISc registration with PLATO. Further research is required to better understand why they are not registered with PLATO and whether an additional branch for remote sensing should be specified through the Geomatics Profession Act.

The results of the survey contribute to the on-going initiative to gain a better understanding of the supply and demand for GISc knowledge and skills in South Africa. Such understanding is 
important for the implementation of the new Geomatics Profession Act 19 of 2013, as well as for the development of the South African Geo-spatial Information Management Strategy. Survey results can inform GISc capacity building initiatives to ensure that the supply of GISc knowledge and skills meets the demand.

\section{Acknowledgements}

This research was partially supported by the Geo-Information Society of South Africa (GISSA). We express our gratitude to the team of experts from the South African GISc industry who provided feedback on draft versions of the survey. A special word of thanks to respondents who took the time to complete the survey. Finally, we are grateful for the reviewer comments, which helped us to improve the article.

\section{References}

Coetzee, S and Eksteen, S 2012, 'Tertiary education institutions in Africa: Cloudy with a chance of GISc education in some countries', South African Journal of Geomatics, 1(2), pp. 119-132.

Cipriano, P, Easton, C, Roglia, E and Vancauwenberghe, G 2013, A European Community of SMEs built on Environmental Digital Content and Languages, D1.3 Final Report, viewed 7 May 2014, $<$ www.smespire.eu/publications/>.

Department Public Service and Administration (DPSA) of South Africa 2011, 'Annexure A. Occupation specific dispensation (OSD) - Engineers and related professions', Implementation of the Occupational Specific Dispensation (OSD's) for engineers and related professions and occupations, viewed 21 May 2014, <www.dpsa.gov.za/dpsa2g/r_documents.asp $>$.

DiBiase, D, DeMers, M, Johnson, A, Kemp, K, Luck, AT, Plewe, B, \& Wentz, E (Eds.) 2006, Geographic Information Science and Technology Body of Knowledge, Association of American Geographers: Washington, USA.

Downman, I and Roy, D 2011, A model for nation building. Geospatial World, May 2011, pp. 34-42.

Du Plessis, H 2012, 'Tensions at GISc Professional Registration workshop', PositionIT, viewed 19 July 2014, <http://www.ee.co.za/article/tensions-at-gisc-profesional-registration-workshop.html>.

Du Plessis, H and Van Niekerk, A 2013, 'A Comparison of Geographical Information Science Competency Requirements', South African Journal of Geomatics, 2(3), pp. 206-217.

Du Plessis, H and Van Niekerk, A 2014, 'A New GISc Framework and Competency Set for Curricula Development at South African Universities', South African Journal of Geomatics, 3(1), pp. 1-12.

Eksteen, S, Coetzee, S and Grundling, C 2012, 'Tertiary GISc education at African universities: Is the sun shining in South Africa?', Proceedings of GISSA Ukubuzana 2012, Kempton Park, South Africa, 2-4 October 2012.

Geo-information Society of South Africa (GISSA) Gauteng General Meeting, 19 July 2013, University of Pretoria, Pretoria, South Africa.

Geo-information Society of South Africa (GISSA) Website, viewed 17 July 2014, $<$ http://www.gissa.org.za $>$. 
Henttu, H, Izaret, J-M, Potere, D 2012, 'Geospatial Services: A \$1.6 Trillion Growth Engine for the US Economy', The Boston Consulting Group, viewed 19 July 2014,

$<$ https://www.bcg.com/documents/file109372.pdf $>$.

Hill, T and Nel, EL 1996, 'The state of Geographical information Systems (GIS) training and research in South African universities', Development Southern Africa, 13(1), pp. 149-154.

Marais, H 2008, 'The challenges of GIS education and training: GIS use municipal urban and regional planning', Asian Conference on Remote Sensing, viewed 20 March 2014, <www.a-a-rs.org/acrs/proceeding/ACRS2008/Papers/TS 24.1.pdf>.

Oxera Consulting Ltd. 2013, 'What is the economic impact of Geo services?', Summary report prepared for Google, viewed 21 May 2014, <www.oxera.com/Latest-Thinking/News/January-2013/Oxera-quantifiesthe-benefits-of-Geo-services-to-g.aspx $>$.

Rautenbach, V, Coetzee, S, Smit, J, Muzondo, I and du Plessis, H 2012, 'Identifying the target audiences, media and messages for SDI education and training in South Africa', Proceedings of the GISSA Ukubuzana 2012, Kempton Park, South Africa, 2-4 October 2012.

Roos, A 2014, 'GISSA Annual Report for FY2013', GISSA Annual General Meeting, Pretoria, South Africa, 14 March 2014.

Sanjay 2013, 'Business value of geospatial industry', Geospatial World, viewed 21 May 2014, $<$ http://geospatialworld.net/Professional/ViewBlog.aspx?id=304>.

Statistics South Africa (Stats SA) 2012a, Census 2011, Statistical release (revised) P0301.4.

Statistics South Africa (Stats SA) 2014, Quarterly Labour Force Survey, Quarter 1, 2014, Statistical release P0211.

Statistics South Africa (Stats SA) 2012b, Regional Economic Growth, viewed 7 May 2014 $<$ www.statssa.gov.za/articles/16 Regional estimates.pdk $>$.

United States Department of Labor Employment and Training Administration (DOLETA) 2011. High Growth Job Training Initiative, viewed 19 July 2014, $<$ http://www.doleta.gov/brg/jobtraininitiative/eta default.cfm\#TargetedIndustries $>$.

United States Department of Labor Employment and Training Administration (DOLETA) 2014. $O * N E T$ Online, viewed 7 May 2014, < online.onetcenter.org/>.

Van Zwieten, C 2012, ‘OSD complicates professional registration’, PositionIT, viewed 19 July 2014

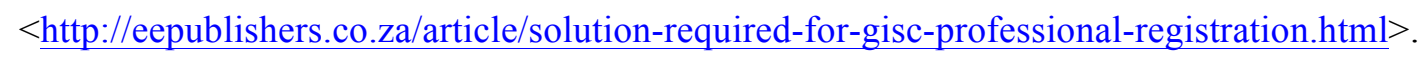

